\title{
New regulations in dispute
}

\section{Washington}

JUDGING from criticisms aired last week, the US government's coordinated framework for biotechnology regulation may not be so coordinated after all. Comments from several trade groups suggest that the framework has failed to clarify agency jurisdiction and has cast the regulatory net too widely. The results could be cost and confusion for an industry dominated by small companies with little spare change.

The Industrial Biotechnology Association (IBA) and the Association of Biotechnology Companies (ABC), both major advocates of commercial biotechnology, voiced their concerns in their formal responses to the framework, published in June under the aegis of the Office of Science and Technology Policy (see $\mathrm{Na}$ ture 321, 458; 1986). The document includes definitions of organisms subject to federal review and statements of policy from the three agencies involved - the Food and Drug Administration (FDA), the Environmental Protection Agency (EPA) and the United States Department of Agriculture (USDA).

There have been many detailed complaints since then, but critics are dissatisfied with the overall picture. The framework's primary purpose was to spell out the regulatory interactions between the three federal agencies. Yet IBA, ABC and the Pharmaceutical Manufacturers Association have all pointed to overlapping and uncertain areas of responsibility between the EPA and the USDA.

The framework suggests that one agency be designated the lead agency with primary responsibility, while the other is considered the secondary agency. But it does not elaborate on the role of the secondary agency and thus could lead to conflicting interpretations without avoiding duplication.

$A B C$ notes that a Cornell University researcher has already become entangled in the regulatory web. Gary Harman, at the New York State Agricultural Experiment Station, requested permission last spring to test, in the field, a recombinant Trichoderma fungus created by protoplast fusion. EPA conducted the extensive review required to grant an experimental use permit, then decided last month that the organism did not need one.

In the midst of EPA's review the Animal and Plant Health Inspection Service, a branch of the USDA, was notified of Harman's intentions and began its own review. Despite the thorough scrutiny by the EPA, the USDA asked for additional data. And despite the EPA's earlier decision, USDA says that allowing Harman to proceed without further review would violate its statutes.
Within the vagaries of jurisdiction, the trade associations have also found several proposed definitions unpalatable The definition of "pathogen" has roused the objections of the IBA because it includes microorganisms that have inserted genetic material from known pathogens, regardless of whether the inserts are involved in pathenogenic mechanisms. The association wants several exemptions based on the likelihood of conferring pathogenicity with the transferred sequences. Such modifications in definition would not remove the recombinant organism from regulatory consideration, but would ease a stiff review.

Intimately related to the issue of reviewing organisms for environmental release is the determination of exactly what constitutes environmental release. Both IBA and $\mathrm{ABC}$ feel that no consensus has been achieved within the industry or among the agencies to arrive at a general

\section{Chernobyl fallout}

\section{Pugwash's radioactive trousers}

A LETTER by scientists from the University of Groningen is published on page 399 of this issue. The group has been investigating core fragments from Chernobyl "inadvertantly" picked up by travellers returning from the Soviet Union.

A colourful and anecdotal account of this work was given last month at the 36 th Pugwash conference on Science and World Affairs in Budapest. Dr Phillip Smith, a physicist at Groningen, described how a Dutch student, returning from Kiev shortly after the accident, brought in his

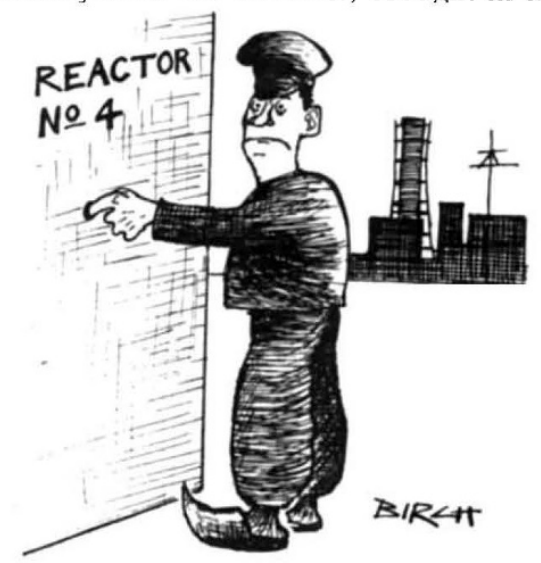

trousers for screening, and how they had revealed "hot" particles of plutonium, americum and curium. The Soviet delegates to Pugwash did not contradict this account, although Academician Vitalii Goldanskii contended that Dr Smith was being unnecessarily alarmist in mentioning plutonium. The "hotspots" he said, were predominantly curium, for which the definition. Likewise, the issue of containment, which can carry enormous financial demands, has yet to be hammered out. The EPA has expressed willingness to loosen monitoring of recombinant organisms used only in closed systems such as fermentation vessels; but the characterization of a closed system turns on containment standards.

The trade associations also used their comments on the framework to frame their less technical criticisms. EPA is commended for its shift from process-based to product-based policy, a shift urged by the industry in 1984.

Despite the conflicts surrounding regulatory policy,present tensions may well dissipate as intepretation takes the place of speculation. FDA, the agency most conversant with recombinant DNA regulation, issued the tersest policy statement and received the warmest remarks. The industry has appreciated FDA's case-bycase approach. But as the number of recombinant products mounts, the agency may no longer be able to take the time for individual attention.

Karen Wright
That Pugwash should be discussing the Chernobyl fallout at all represented a new departure. The hazard of fallout was discussed by the first Pugwash Conference almost 30 years ago, but then it was the fallout from nuclear tests which posed the main risk.

It was Dr Joseph Rotblat of London who suggested some months ago that since, after all, Pugwash was a gathering of scientists there should be at least one scientific lecture, and after Chernobyl, the issue of reactor safety seemed an obvious choice. In the event, the information content of the formal presentations was marred by the fact that the longterm projections of the effect of fallout in Europe had been based on British and Dutch computer models which had assumed that the emissions had lasted hours rather than (as the Soviet report to the International Atomic Energy Authority revealed) two weeks.

But the idea of using a non-confrontational forum such as Pugwash to air issues of international public concern is an interesting one, which if repeated could well add a new and valuable dimension to the work of the Pugwash movement. Unfortunately, the final statement from the conference, which concentrated on the major issues of a comprehensive test-ban, the reduction of East-West tensions and the destabilizing effects of the debts of developing countries, made no mention of any plans to repeat $\mathrm{Dr}$ Rotblat's initiative. 